\title{
ANALISIS HUKUM DAMPAK BELUM DIRATIFIKASI KERANGKA KERJA KONVENSI PENGENDALIAN TEMBAKAU (FRAMEWORK CONVENTION ON TOBACCO CONTROL) BAGI INDONESIA
}

\author{
Aditia Bagus Santoso \\ Fakultas Hukum Universitas Riau \\ Widia Edorita dan Ledy Diana \\ Fakultas Hukum Universitas Riau
}

abstract

Framework Convention on Tobacco Control (FCTC) is an international treaty for tobacco control efforts for world health under the WHO. Indonesia has not ratified the treaty as far as the impact that would be acceptable for Indonesia, while many countries in the world have ratified and observed what steps should be taken in the case of the strategic Indonesia.

Keywords: Impact, Ratification, Framework Convention On Tobacco Control

\begin{abstract}
abstrak
Framework Convention On Tobacco Control (FCTC) adalah perjanjian internasional yang mengendalikan upaya tembakau bagi dunia kesehatan di bawah WHO. Indonesia belum meratifikasi FCTC sejauh dampak yang akan diterima Indonesia belum meratifikasi perjanjian tersebut ke dalam hukum nasional sementara banyak negara di dunia yang telah meratifikasi dan mengamati apa langkah-langkah yang harus diambil dalam hal oleh Indonesia yang strategis.
\end{abstract}

Kata Kunci: Dampak, Ratifikasi, Framework Convention On Tobacco Control.

\section{A. Pendahuluan}

Salah satu bentuk perwujudan dalam memelihara hubungan kerja sama antar negara dituangkan dalam bentuk perjanjian (internasional). Pengaturan yuridis tentang perjanjian internasional ini telah dikodifikasikan melalui Konvensi Wina 1969 tentang Hukum Perjanjian. ${ }^{1}$

\footnotetext{
${ }^{1}$ Yudha Bhakti Ardhi wisastra, Hukum Internasional: Bunga Rampai, (Bandung: Penerbit PT Alumni, 2003), hlm.106.
} 
Pengertian Perjanjian Internasional menurut Konvensi Wina 1969 ialah suatu persetujuan internasional yang diadakan antara negara-negara dalam bentuk yang tertulis dan diatur oleh hukum internasional, baik yang berupa satu instrumen tunggal atau berupa dua instrumen yang saling berkaitan tanpa memandang apapun juga namanya. ${ }^{2}$ Menurut Statuta Mahkamah Internasional dalam pasal 38 ayat (1), Perjanjian Internasional merupakan salah satu sumber hukum internasional. ${ }^{3}$ Pada umumnya hukum internasional diartikan sebagai himpunan dari peraturan-peraturan dan ketentuan-ketentuan yang mengikat serta mengatur hubungan antara negaranegara dan subjek-subjek hukum lainnya dalam kehidupan masyarakat internasional. ${ }^{4}$

Indonesia merupakan salah satu negara yang sudah banyak melakukan perjanjian internasional, baik itu bilateral maupun multilateral dan sudah banyak pula yang diratifikasi menjadi undang-undangataupun keputusan presiden. Namun, ada beberapa perjanjian internasional yang tidak diratifikasi oleh Indonesia, karena berbagai alasan. Selain Konvensi Wina 1969, salah satunya adalah Kerangka Kerja Konvensi Pengendalian Tembakau (Framework Convention on Tobacco Control)yang selanjutnya akan disebut FCTC, yang diprakarsai oleh Badan Kesehatan Dunia (World Health Organization/WHO). ${ }^{5}$

WHO telah mengeluarkan FCTC yang merupakan perjanjian internasional, efektif berlaku sejak tanggal 27 Februari 2005. Di dalam artikel 3 FCTC, konvensi tersebut bertujuan untuk melindungi generasi saat ini dan yang akan datang dari kehancuran kesehatan, konsekuensi sosial, lingkungan dan ekonomi yang diakibatkan oleh rokok dan paparan asapnya. ${ }^{6}$

Indonesia merupakan negara ketiga dengan jumlah perokok terbesar di dunia setelah Cina dan India ${ }^{7}$ dengan jumlah perokok di Indonesia sebanyak 4,8\% dari 1,3 miliar orang di dunia. ${ }^{8}$ Indonesia pun menjadi salah satu negara dengan perokoknya merupakan anak-anak di bawah umur, sekitar satu juta anak-anak di bawah umur 16 tahun sudah merokok. Buruknya

\footnotetext{
2 I Wayan Parthiana, Hukum perjanjian Internasional Bagian 1, (Bandung: Penerbit Mandar Maju, 2002), hlm.14.

${ }^{3}$ Mochtar Kusumaatmadja dan Etty R. Agoes, Pengantar Hukum Internasional, (Jakarta: PT. Alumni, 2003), hlm. 114.

${ }^{4}$ Boer Mauna. Hukum Internasional: Pengertian Peranan dan Fungsi Dalam Era Dinamika Global, Edisi Kedua, (Bandung: Penerbit P.T.Alumni,2010).

5 http://www.who.int/fctc/cop/sessions/new_treaty/en/index.html(terakhirdiakses, $\quad 20$ Desember 2012)

${ }^{6}$ WHO Framework Conventionon Tobacco Control, Fifth-Sixth World Health Assembly.

7 http://www.who.int,ReportonGlobalTobaccoEpidemic.(terakhir diakses pada tanggal 21 Februari 2013)

8 http://www.antaranews.com/berita/313477/jumlah-perokok-indonesia-terbanyak-ketiga di- dunia (terakhir diakses pada 21 Februari 2013)
} 
sepertiga dari anak Indonesia mencoba merokok sebelum umur 10 tahun. ${ }^{9}$ Data Global Youth Tobacco Survey (2006-2009) menyebutkan bahwa prevalensi perokok remaja yang bersekolah usia antara 13-15 tahun meningkat dua kali lipat selama kurun waktu 3 tahun terakhir, yaitu 20062009. ${ }^{10}$

Di sisi lain Indonesia merupakan negara dengan mayoritas perokok di Indonesia (92\%) mengonsumsi kretek yang merupakan rokok tradisional yang dibuat dari tembakau, kuncup cengkeh, dan bumbu saus baik yang dibuat tradisional oleh tangan maupun oleh mesin. Indonesia juga negara terbesar kelima pasar tembakau berdasarkan volume penjualan. Di bidang produksi, Indonesia merupakan salah satu negara produsen tembakau terbesar di dunia. Pada tahun 2009 Indonesia berhasil memproduksi tembakau sebanyak 181.319 ton. $^{11}$

Dari sektor tenaga kerja, secara keseluruhan industri tembakau menyerap tenaga kerja sekitar 4.154 juta tenaga kerja, di mana 93,77\% diserap kegiatan usaha tani termasuk pascapanen, sedangkan tenaga kerja di sektor pengolahan rokok hanya menyerap sekitar $6,23 \% .^{12}$ Lebih rincinya 1,25 juta orang telah menggantungkan hidupnya bekerja di ladang cengkeh dan tembakau, 10 juta orang terlibat langsung dalam industri rokok, dan 24,4 juta orang terlibat secara tidak langsung dalam industri rokok. ${ }^{13}$ Dari uraian tersebut muncul beberapa permasalahan, yaitu 1) apakah yang diatur dalam kerangka kerja konvensi pengendalian tembakau (Framework Convention On Tobacco Control)?; 2) apakah dampak negatif belum diratifikasinya kerangka kerja konvensi pengendalian tembakau (framework convention on tobacco control) bagi Indonesia?; dan 3) apakah dampak positif belum diratifikasinya kerangka kerja konvensi pengendalian tembakau (framework convention on tobacco control) bagi Indonesia?

\section{B. Pembahasan}

\section{Pengaturan Perjanjian Internasional di Indonesia}

Perjanjian internasional yang dibuat antar negara diatur dalam Vienna Convention on the Law of Treaties 1969 (Konvensi Wina 1969). Konvensi

\footnotetext{
9 Menurut ABC News dalam Theweek.com/article/in dex/219209/indonesias-smokin gbabies- epidemic(terakhir diakses 25 Februari 2013)

10 www.depkes.go.id /index.php/berita/press-release/ 2078-merokok-membahayakankesehatan-dan-merugikan-perekonomian-masyarakat.html (terakhir diakses pada 28 Februari 2013)

11 Herjuno Ndaru Kinasih, et.al., Tembakau, Negara dan Keserakahan Modal Asing, (Jakarta: Indonesia Berdikari, 2012),hlm. 69.

${ }^{12}$ Herjuno Ndaru Kinasih,et.al.Op.Cit.,hlm.78.

13 M.kompasiana.com /post/bisnis/2011/06/01/paradoks-cukai-rokok-pemasok-rp-627triliun- apbn-2011/ (terakhir diakses pada 28 februari 2013)
} 
ini berlaku pada 27 Januari 1980. Konvensi ini memuat seperangkat peraturan komprehensif mengenai pembentukan, penafsiran, dan pengakhiran perjanjian. ${ }^{14}$ Sebelum adanya Konvensi Wina 1969 yang mengatur tentang Perjanjian Internasional antar negara baik bilateral maupun multilateral, perjanjian internasional diadakan berdasarkan asas-asas seperti good faith, pacta sunservanda dan perjanjian tersebut terbentuk atas consent dari negara-negara di dalamnya. ${ }^{15} \mathrm{Di}$ samping ketiga prinsip ini, masih terdapat prinsip-prinsip hukum umum lainnya yang juga menjadi landasan dari hukum perjanjian internasional.

Konvensi ini sudah mulai berlaku efektif pada tanggal 27 Januari 1980, namun hingga sekarang Indonesia belum meratifikasi konvensi tersebut, sehingga tidak terikat kepada isi konvensi tersebut. Namun karena ketentuan-ketentuan konvensi tersebut telah menjadi hukum kebiasaan internasional, sehingga dalam praktek isi konvensi tersebut mau tidak mau mengikat Indonesia. ${ }^{16}$

Meski Indonesia tidak meratifikasi konvensi tersebut, dalam UndangUndang Dasar 1945 terdapat landasan hukum pembuatan perjanjian, yaitu dalam pasal 11 yang menyatakan bahwa "Presiden dengan persetujuan Dewan Perwakilan Rakyat menyatakan perang, membuat perdamaian, dan perjanjian dengan negara lain". ${ }^{17}$ Setelah itu dikeluarkanlah Surat Presiden RI No.2826/HK/60, 22 Agustus 1960 tentang pembuatan perjanjian dengan negara lain sebagai usaha untuk menjelaskan ketentuan Pasal 11 UndangUndang Dasar $1945 .^{18}$

Lahirnya Undang-Undang Nomor 20 Tahun 2004 tentang Perjanjian Internasional yang mengatur lebih lanjut tentang perjanjian internasional yang diatur sebelumnya pada Pasal 11 Undang-Undang Dasar 1945 dan Surat Presiden No.2826/HK/60. Undang-Undang Nomor 20 Tahun 2004 tentang Perjanjian Internasional menjadi pedoman bagi Indonesia untuk membuat perjanjian internasional dengan negara lain maupun organisasi internasional hingga sekarang.

\section{Pengaturan Pengendalian Tembakau di Indonesia}

Hingga saat ini, Indonesia belum meratifikasi Kerangka Konvensi Pengendalian Tembakau, namun Indonesia sudah memiliki peraturan yang

\footnotetext{
${ }^{14}$ Huala Adolf, Hukum Ekonomi Internasional Suatu Pengantar, (Jakarta: PT. Raja Grafindo Persada,1997), hlm.103

${ }^{15}$ Ade Pratiwi Susanty, "Tinjauan Yuridis Terhadap Kewenangan Daerah dalam Membuat Perjanjian Internasional diIndonesia ”Skripsi, (Fakultas Hukum Universitas Riau, 2010), hlm.45.

${ }^{16}$ Huala Adolf, Op.Cit., hlm. 103.

${ }^{17}$ Boe rMauna, Op.Cit., hlm. 163.

${ }^{18}$ Ibid.
} 
mengatur tentang pengendalian tembakau di dalam negeri yaitu dalam Undang-Undang Nomor 36 Tahun 2009 tentang Kesehatan dalam pasal 113116 yang berisi tentang Pengamanan Produk Tembakau sebagai Zat Adiktif bagi Kesehatan.

\section{Sejarah Pengendalian Tembakau di Indonesia}

Pada masa Pemerintahan B.J.Habibie didirikan Forum Komunikasi Nasional di bawah naungan Badan Obat dan Makanan, Kementerian Kesehatan sebagai wadah konsolidasi antara LSM dan staf pemerintah dalam isu kontrol tembakau. Lebih lanjut, regulasi pemerintah untuk kontrol tembakau ditetapkan pada tanggal 5 Oktober 1999 dengan disahkannya Peraturan Pemerintah Nomor 81 Tahun 1999 tentang Pengamanan Rokok bagi Kesehatan yang merupakan peraturan pelaksana Pasal 44 UndangUndang Nomor 23 Tahun 1992.

Pada masa Presiden Abdurahman Wahid, Peraturan Pemerintah Nomor 81 Tahun 1999 diamandemen ke Peraturan Pemerintah Nomor 38 Tahun 2000 yang mana ketentuan tentang periklanan diperlunak serta terdapat batas waktu implementasi pasal tentang kandungan tar dan nikotin dalam kemasan rokok.

Namun ketentuan ini tidak lugas dan tidak disertai sanksi. Lalu diperbaharui lagi oleh Peraturan Pemerintah Nomor 19 Tahun2003. ${ }^{19}$ Amandemen yang ketiga ini diadopsi oleh Presiden Megawati. Amandemen ini menghilangkan pasal tentang kandungan tar dan nikotin. Sebagai gantinya, setiap produk rokok harus melalui uji coba di laboratorium terakreditasi.

Dan Peraturan Pemerintah yang terbaru mengatur tentang pengendalian tembakau adalah Peraturan Pemerintah Nomor 109 Tahun 2012 tentang Pengamanan Bahan yang mengandung Zat Adiktif berupa Produk Tembakau Bagi Kesehatan yang disahkan pada tanggal 24 Desember 2012. Peraturan Pemerintah ini merupakan aturan untuk menekan seluruh lini industri tembakau, mulai dari produksi, pemasaran, hingga konsumsi. PP ini mengadopsi sebagian dari prinsip-prinsip dan pasal-pasal yang terkandung dalam FCTC.

\section{Kerangka Kerja Konvensi Pengendalian Tembakau (Framework Convention On Tobacco Control)}

Kerangka Kerja Konvensi Pengendalian Tembakau adalah perjanjian negosiasi pertama di bawah Badan Kesehatan Dunia (World Health

\footnotetext{
19 Titon Slamet Kurnia, Hakatas Derajat Kesehatan optimal sebagai HAM di Indonesia, (Bandung: Penerbit Alumni, 2007), hlm. 153.
} 
Organization/WHO). Kerangka Kerja Konvensi Pengendalian Tembakau ini adalah perjanjian dasar mengenai aturan setiap orang mengenai standar yang tinggi terhadap kesehatan.

Konvensi ini mulai berlaku secara internasional pada 27 Februari 2005, yaitu 90 hari setelah disetujui, ratifikasi, diterima, atau disetujui oleh 40 negara. Dan FCTC sekarang sudah menjadi Hukum Internasional karena sudah diratifikasi oleh lebih dari 40 negara.

Kerangka Kerja Pengendalian Tambakau (Framewok Convention on Tobacco Control) terdiri dari Mukadimah, $11 \mathrm{Bab}, 38$ Pasal, dan 2 lampiran tentangasal mula lahirnya FCTC dan sejarah FCTC. Bagian awal berisi tentang Preambule atau Mukadimah yang berisi tentang pengakuan, penggambaran dan komitmen para peserta konvensi.

\section{Alasan Pemerintah Belum Meratifikasi Kerangka Kerja Konvensi Pengendalian Tembakau (Framework Conventionon Tobacco Control/ FCTC)}

Indonesia menjadi satu-satunya negara di Asia Pasifik yang belum meratifikasi FCTC. $^{20}$ Amerika serikat juga merupakan salah satu negara yang belum meratifikasi FCTC hingga sekarang. ${ }^{21}$ Amerika Serikat enggan meratifikasi konvensi tersebut karena mempunyai kepentingan ekonomi dengan tembakau sebagai bahan dasarnya. Produksi tembakau telah menjadi industri yang berkembang pesat dan menghasilkan pendapatan yang besar bagi Amerika Serikat.

Penulis mencoba menelaah yang menjadi alasan Pemerintah Indonesia belum meratifikasi FCTC dengan membandingkan dengan negara-negara lain. Alasan-alasan tersebut adalah:

\section{a. Alasan Ekonomi}

Indonesia merupakan negara dengan status sebagai negara produsen tembakau terbesar di dunia, bahkan pada tahun 2007, Indonesia berada pada peringkat ke-6 sebagai negara produsen daun tembakau terbesar di dunia. ${ }^{22}$ Kontribusi industri tembakau dan rokok dapat dilihat dari dua sisi. ${ }^{23}$ Pertama konstribusi terhadap Produk Domestik Bruto (PDB). Kedua, dari sisi penerimaan negara melalui cukai rokok.

Peran komoditas tembakau yang cukup nyata dalam perekonomian nasional adalah sebagai sumber penerimaan negara dan cukai. Nilai

\footnotetext{
${ }^{20}$.http://www.who.int /fctc/signatories_parties/en/index.html (terakhir diakses, 20 Desember 2012)

${ }^{21}$ Herjuno Ndaru Kinasih,et.al.,Op.Cit.,Hlm. 168.

${ }^{22}$ Herjuno Ndaru Kinasih,et.al.,Op.Cit.,hlm. 71.

${ }^{23}$ Ibid, hlm. 76.
} 
penerimaan dari cukai yang dari tahun ke tahun terus meningkat, yaitu dari Rp. 11,1 triliun pada tahun 2001 menjadi sekitar Rp. 51 triliun pada tahun 2008 dan 60,7 triliun pada tahun 2011, peningkatan yang sangat besar.

Penerimaan negara dari cukai tembakau terbilang besar dibandingkan dengan penerimaan dari sektor sumber daya alam nonmigas seperti pertambangan umum, kehutanan, perikanan, dan pertambangan panas bumi. Nilai pendapatan cukai Rp. 60,7 triliun hampir lima kali lipat dari pendapatan sumber daya alam di luar migas yang sebesar Rp. 12,9 triliun. Bahkan penerimaan cukai hampir separuh dari seluruh pendapatan negara yang diperoleh dari eksploitasi migas.

\section{b. Alasan Tenaga Kerja dan Lapangan Pekerjaan.}

Bisnis tembakau merupakan bisnis besar yang melibatkan berbagai aktor diberbagai negara. Berdasarkan data International Labour Organization (ILO) di Indonesia terdapat 24 juta jiwa yang bergantung pada industri hasil tembakau. ${ }^{24}$ Petani merupakan salah satu pihak yang paling berperan penting dan dianggap pihak yang paling lemah di rantai makanan industri tembakau.

Selain akan hilangnya lapangan pekerjaan bagi ribuan industri kecil dan menengah yang hidup dari tembakau, pembangunan sosial dan ekonomi nasional juga akan terhenti. Industri kecil dan menengah tidak hanya menghidupi jutaan masyarakat yang terlibat dalam mata rantai industri, melainkan juga secara tidak langsung menggerakan perekonomian nasional secara keseluruhan. ${ }^{25}$

\section{c. Alasan Budaya dan Sejarah}

Kretek merupakan rokok tradisional yang dibuat dari tembakau, kuncup cengkeh, dan bumbu "saus" baik yang dibuat tradisional oleh tangan maupun oleh mesin. Jenis rokok ini merupakan satu-satunya yang diproduksi di dunia oleh Indonesia. Dan jenis roko kini pun menggunakan tembakau dengan kualitas yang terbaik yang hanya dapat dihasilkan di daerah tertentu di Indonesia. Sehingga dapat dilihat bahwa kretek menjadi budaya Indonesia.

Tidak hanya kontribusinya kepada pendapatan negara, dinamika sosial budaya ekonomi masyarakat Indonesia pun tidak terlepas dari peran kretek. Kretek menjadi entitas yang menjadi harta karun bagi para pencari kekayaan di seluruh dunia karena nilai ekonomi dan budayanya yang sangat tinggi.

\footnotetext{
${ }^{24}$ Wisnu Brata, Op.Cit.,hlm. 101.

${ }^{25}$ Ibid, hlm. 132.
} 


\section{Konsekuensi Hukum Bagi Negara yang Meratifikasi Framework Convention On Tobacco Control/ FCTC}

\section{a. China}

China merupakan negara produsen tembakau terbesar di dunia. Industri tembakau China menghasilkan rokok untuk mayoritas konsumsi dalam negeri. Rokok merupakan komoditas yang telah lama menjadi bagian dari budaya China. China menjadi negara dengan produsen tembakau terbesar di dunia. Tercatat pada tahun 2011, China memproduksi lebih dari 2,3 triliun batang rokok. ${ }^{26}$

China meratifikasi FCTC pada tanggal 11 Oktober 2005 dan melaksanakannya pada tanggal 9 Januari 2006. Sudah hampir 7 tahun China meratifikasi FCTC ke dalam hukum nasionalnya. ${ }^{27}$ Survei CDC China pada tahun 2010 menyatakan bahwa jumlah perokok umur 15 tahun lebih di China sebesar 52,9\%, sama dengan jumlah di tahun 2002. Lebih buruknya lagi, jumlah perokok anak-anak meningkat selama FCTC diimplementasikan di China. ${ }^{28}$

Walau sudah diratifikasinya FCTC yang berfungsi untuk mengendalikan tembakau, industri tembakau China tetap berkembang dan terus tumbuh. Sehingga FCTC hanya dijadikan sebagai alat agar China dapat menyampaikan kepentingannya di dalam perjanjian internasional tersebut. China memiliki beberapa kepentingan di dalam FCTC. Pertama, China memanfaatkan norma internasional tersebut untuk memblokir perdagangan liberal produk tembakau sehingga dapat mempertahankan status monopoli perdagangan tembakau domestik China. Kedua, China ingin memanfaatkan FCTC untuk menyelesaikan permasalah perdagangan gelap. Ketiga, aturan yang ditetapkan di dalam FCTC jika diimplementasikan maka akan menguntungkan perkembangan ekonomi China jangka panjang. ${ }^{29}$

\section{b. Luksemburg}

Luksemburg adalah anggota Uni Eropa yang merupakan negara kecil dengan luas sekitar 2.600 kilometer persegi. Luksemburg merupakan salah satu negara di Eropa yang menanam tembakau mesti jumlahnya sedikit (kurang dari $0,1 \%$ dari seluruh total produksi pertanian Uni Eropa). Meskipun di Uni Eropa terdapat wacana tembakau dan rokok harus dikenai pajak tinggi, hanya Luksemburg, Perancis, dan Belgia yang menerapkannya. Negara dengan tingkat konsumsi dan produksi rokok yang tinggi akan

\footnotetext{
${ }^{26}$ Herjuno Ndaru Kisasih,et.al.,Op.Cit.,hlm.46.

${ }^{27}$ www.who.int/fctc/ signatories_parties/en/index.html (terakhir diakses pada 22 Mei 2013).

${ }^{28}$.http://www.princet on.edu/ pcglobal/conferences/GLF/jin.pdf (terakhir diakses pada 23 Mei 2013).

${ }^{29}$ Ibid.
} 
menolak kebijakan itu, seperti Jerman, Italia, dan Yunani. ${ }^{30}$

Kebijakan cukai rokok yang tinggi akan menguntungkan perekonomian Luksemburg, khususnya dalam hal pajak. Konsumen rokok di Luksemburg kebanyakan besar warga asing. Pendapatan Luksemburg dari cukai rokok sangat tinggi, mencapai 2,08\% dari PDB. Selain mendapatkan keuntungan dari warga asing yang melintas, Luksemburg juga memperoleh keuntungan dari bisnis tembakau dari limpahan cadangan produksi tembakau negara tetangganya, terutama Jerman dan Perancis.

Luksemburg belum menerapkan sepenuhnya aturan mengenai kawasan bebas rokok, seperti negara-negara di sekitarnya, misalnya Belgia. Hal ini untuk memfasilitasi Luksemburg sebagai negara transit yang memungkinkan warga asing atau wisatawan untuk merokok. ${ }^{31}$

\section{Dampak Negatif Kerangka Kerja Konvensi Pengendalian Tembakau (Framework Convention On Tobacco Control) bagi Indonesia sebagai Negara yang Belum Meratifikasi.}

Ekspor Impor terkait erat dengan perdagangan antar negara. Tentunya hal tersebut berhubungan erat dengan perekonomian dan hubungan bilateral suatu negara dengan negara lain. Dengan tidak diratifikasinya FCTC, maka akan berimbas kepada ekspor dan impor Indonesia. Walaupun tentunya tidak akan berpengaruh signifikan bagi ekspor impor Indonesia, namun hal itu akan menyebabkan banyaknya terdapat tindak kecurangan dalam ekspor dan impor tembakau dan produk hasil tembakau.

Karena di dalam FCTC terdapat aturan mengenai pengaturan tentang perdagangan gelap dan ilegal bagi perdagangan tembakau dan produk hasil tembakau. Dalam ayat 15 FCTC mengharuskan para pihak dalam konvensi ini mengambil langkah untuk memberantas semua bentuk perdagangan ilegal, termasuk pemalsuan, dan menyatakan bahwa kerja sama nasional, regional, dan global dalam masalah ini adalah komponen penting dalam pengendalian tembakau. ${ }^{32}$

Perdagangan gelap dan ilegal tersebut dapat merugikan negara dari sektor pendapatan negara. Karena produk-produk tersebut masuk ke pasar Indonesia tanpa sepengetahuan Negara, yaitu dengan tidak membayar bea masuk, cukai ataupun PPN (Pajak Pertambahan Nilai), sehingga negara mengalami kerugian dari tindakan tersebut. Tercatat total penerimaan negara

\footnotetext{
${ }^{30}$ Herjuno Ndaru Kinasih,et.al.,Op.Cit.,hlm.101.

${ }^{31}$ Ibid, hlm. 102.

${ }^{32}$.http://www.sampoerna.com/id_id/tobacco_regulation/what_is_illicit_trade/pages/what_is _il licit_trade.aspx (terakhir diakses pada 23 Maret 2013).
} 
dari cukai hasil tembakau yaitu berjumlah Rp. 64,8 triliun pada tahun $2011 .^{33}$

Konvensi ini mempunyai tujuan untuk mempromosikan hidup sehat tanpa adanya asap rokok bagi masyarakat. Karena banyak penelitian yang menunjukan bahwa angka kematian karena rokok sangat tinggi. Oleh karena itu, mempunyai korelasi erat dengan perlindungan negara untuk 'right to life ${ }^{34}$ Hak atas hidup juga terkait dengan kondisi yang harus dibangun oleh satu negara untuk menghindari masyarakatnya dari kematian karena sesuatu yang bisa dicegah, seperti misalnya mengendalikan rokok dan sebagainya.Dengan tidak meratifikasi FCTC, membuat tingkat kesehatan Indonesia lebih rendah dibandingkan negara lain. Dalam FCTC terdapat pengaturan tentang kesehatan, terutama terhadap masyarakat, anak-anak, dan lingkungan. ${ }^{35}$

Pengakuan yang di dapat oleh suatu negara dari negara lain berhubungan erat dengan pergaulan yang dilakukan oleh suatu negara di dalam dunia internasional. Dengan aktifnya suatu negara di dalam dunia internasional, maka pergaulan negara tersebut juga akan semakin meningkat dengan negara lain maupun di dalam organisasi internasional. Hal itu akan berdampak mudahnya suatu negara untuk membuat suatu perjanjian internasional serta kerja sama lainnya yang menguntungkan bagi negara tersebut. Sehingga dengan tidak diratifikasinya FCTC oleh pemerintah Indonesia, Indonesia mendapat kerugian dalam hubungan bilateral dengan negara lain terutama negara yang sudah meratifikasi FCTC ataupun organisasi internasional. Indonesia dapat dikucilkan oleh negara lain dalam hal pergaulan internasional. Karena Indonesia merupakan negara yang ikut serta aktif di dalam FCTC dari awal hingga akhir pembahasan.

Indonesia pun juga akan dikucilkan di dalam forum internasional yang membahas kesehatan terutama yang berkaitan dengan pengendalian tembakau. Indonesia pun dikatakan akan merendahkan dan menyabotase upaya pengendalian tembakau yang dilakukan susah payah oleh negaranegara lain. Hal itu karena terbuka kemungkinan Indonesia menjadi simpul penting beredarnya tembakau yang akan masuk ke negara-negara lainnya, dengan kata lain menciptakan lingkungan merugikan bagi kawasan.

\footnotetext{
${ }^{33}$.APBN2012,UUNo.22/2011APBN-P:APBN2011Perubahandalam http://www.sampoerna.com/id_id/tobacco_regulation/pages/tobacco_taxation_system_in_ indonesia.as px (terakhir diakses pada 23 Maret 2013).

${ }^{34}$ Ifdal Kasim, Ketua Komnas HAM dalam m.voaindonesia.com/1516665.html (terakhir diakses pada 12 Februari 2013).

35 Abdillah Hasan, Peneliti Lembaga Demografi Universitas Indonesia (LDUI) dalam www.beritasatu.com/m obile/bisnis/50164-belum-ratifi kasi-konvensi-tembakau-ri-dia baikan-forum-global.html (terakhir diakses pada 12 Februari 2013).
} 


\section{Dampak Positif Kerangka Kerja Konvensi Pengendalian Tembakau (Framework Convention On Tobacco Control) bagi Indonesia sebagai Negara yang Belum Meratifikasi}

Dengan adanya dampak pengendalian tembakau secara global melalui FCTC berdampak terhadap pengembangan Industri Hasil Tembakau (IHT). Dalam pengembangan IHT di dalam negeri, pemerintah bersama stakeholder terkait telah menyusun roadmap IHT 2007-2020 dengan prioritas untuk jangka menengah (2010-2015) pada aspek penerimaan, kesehatan, dan tenaga kerja, sedangkan untuk jangka panjang (2015-2020) aspek kesehatan menjadi prioritas yang lebih dibandingkan aspek penerimaan dan tenaga kerja. Selain itu, produksi rokok pada tahun 2020 dibatasi maksimal 260 miliar batang.

Indonesia dalam industri tembakau masuk ke dalam 10 besar negara produsen tembakau dengan produksi mencapai 120 ribu ton per tahun, yang artinya tembakau telah menjadi aset sumber daya alam yang memiliki nilai kompetitif di pasar global. ${ }^{36}$ FCTC dianggap beberapa pihak hanya untuk kepentingan tata niaga perusahaan besar yang menginginkan pasar tembakau dunia dan secara otomatis peraturannya akan mematikan perusahaan kecil dan menengah di bidang tembakau. Indonesia tidak akan terikat dengan aturan-aturan dalam FCTC yang menganjurkan untuk mengurangi produksi tembakau dan menggantinya dengan tanaman lain. Dengan begitu, Indonesia pun masih tetap memproduksi tembakau untuk produksi dalam negeri dan untuk ekspor ke luar negeri dalam bentuk tembakau mentah maupun produk hasil tembakau.Terdapat beberapa pasal di dalam FCTC yang akan menggancam industri hasil tembakau dalam negeri, yaitu Pasal 8, 11, dan 13 FCTC. Pasal 8 mengatur tentang kawasan bebas asap rokok, Pasal 11 mengatur tentang Kemasan, dan Pasal 13 mengatur tentang Periklanan.

Industri-industri hasil tembakau dalam negeri akan tetap dapat berproduksi walaupun Amerika Serikat sebagai negara pengimpor kretek Indonesia terbesar sudah melarang impor rokok kretek melaluiFamily Smoking Prevention Tobacco Act tahun 2009. Walaupun begitu, Industri hasil tembakau dalam negeri masih tetap menjadi salah satu industri vital bagi perekonomian nasional dan ikut menyumbang pendapatan terbesar untuk APBN. ${ }^{37}$

Tembakau dari kretek juga merupakan sejarah bagi rakyat Indonesia. Kretek merupakan produk asli buatan Indonesia dan satu-satunya hanya ada di Indonesia. Rokok kretek yang merupakan salah satu kebudayaan di Indonesia akan terancam hilang seiring dengan banyaknya aturan yang

\footnotetext{
${ }^{36}$ Okta Pinanjaya dan Waskito Giri S, Muslihat Kapitalisme Global: Selingkuh Industri Farmasi dengan Perusahaan Rokok AS, (Jakarta: Indonesia Berdikari, 2012), hlm. 12.

${ }^{37}$ Ibid, hlm. XIV.
} 
melarang produksi, konsumsi, dan peredaran rokok kretek di Indonesia maupun seluruh dunia. Dengan tidak diratifikasinya FCTC, rokok kretek masih menjadi salah satu kebudayaan yang dapat diproduksi, konsumsi, dan didistribusi di Indonesia. Sehingga walau kretek tidak dapat lagi bersaing di tingkat internasional dengan adanya peraturan FCTC, kretek masih dapat bersaing di tingkat nasional karena Indonesia pun belum meratifikasi FCTC hingga sekarang.

Dalam Pasal 28 A Undang-Undang Dasar menjelaskan bagaimana setiap warga negara berhak untuk hidup dan mempertahankan hidup dan kehidupannya. Tentunya Pasal ini melindungi warga negaranya untuk mempertahankan hidup dan kehidupannya. Para pihak yang paling dirugikan dengan FCTC adalah para pihak di usaha tembakau di sektor kecil dan menengah yang akan kehilangan penghidupannya sehingga tidak dapat lagi dapat mempertahankan hidupnya. Apalagi di Indonesia di wilayah Temanggung yang mana wilayahnya hanya dapat ditanami dengan tembakau yang akan tumbuh dengan baik dibandingkan tanaman lainnya. ${ }^{38}$ Tentunya dengan diratifikasinya FCTC, maka FCTC bertentangan dengan UndangUndang Dasar.

Pasal 33 ayat (4) menyebutkan bahwa perekonomian nasional diselenggarakan berdasar atas demokrasi ekonomi dengan prinsip kebersamaan, efisiensi berkeadilan, berkelanjutan, berwawasan lingkungan, kemandirian, serta dengan menjaga keseimbangan kemajuan dan kesatuan ekonomi nasional. Tentunya pasal ini juga bertentangan dengan FCTC jikalau hal tersebut jadi diratifikasi. Karena FCTC dapat membuat ketidakseimbangan ekonomi nasional.

Terdapat keuntungan dari tidak diratifikasinya FCTC oleh Indonesia. Yaitu, Indonesia tidak perlu membayar suatu iuran wajib bagi anggota yang terdaftar menjadi anggota FCTC. Dengan tidak meratifikasi FCTC, secara otomatis tidak menjadi anggota FCTC sehingga tidak perlu terikat dengan hak dan kewajiban yang terdapat di dalam FCTC.

\section{Penutup \\ 1. Kesimpulan}

Framework Convention on Tobacco Control atau FCTC merupakan suatu perjanjian internasional yang mewadahi negara-negara untuk membatasi penggunaan tembakau untuk tujuan kesehatan. Indonesia belum meratifikasi FCTC hingga sekarang. Walaupun Indonesia belum meratifikasi FCTC, Indonesia tetap mendapatkan dampak positif dan negatif dari belum diratifikasinya FCTC dari segi ekonomi, budaya, politik dalam negeri dan politik luar negeri.

\footnotetext{
${ }^{38}$ Wisnu Brata, Op. Cit., hlm. 5.
} 
Dampak negatif dari belum diratifikasinya FCTC dari segi ekonomi yaitu meningkatnya perdagangan ilegal tembakau mentah dan produk hasil tembakau. Dari segi budaya, Indonesia tidak mendapatkan dampak negatif dari belum diratifikasinya FCTC. Dari segi politik dalam negeri, Indonesia mendapatkan dampak negatif yakni rendahnya perlindungan terhadap hak atas kesehatan. Dari segi politik luar negeri, Indonesia mendapatkan dampak negatif yakni dikucilkannya Indonesia dari dunia internasional yang terkait dengan pengendalian tembakau.

Dampak positif dari belum diratifikasinya FCTC oleh Indonesia dalam segi ekonomi yaitu pengembangan Industri Hasil Tembakau (IHT) di Indonesia; 1) terjaganya produksi tembakau dalam negeri; dan 2) tetap terjaganya industri hasil tembakau dalam negeri. Dari segi budaya yaitu tetap terjaganya rokok kretek. Dari segi politik dalam negeri yaitu tidak bertentangan dengan Undang-Undang Dasar dan Undang-Undang. Dari segi politik luar negeri yaitu Indonesia tidak terdaftar jadi anggota FCTC yang dengan otomatis Indonesia terbebas dari segala macam biaya biaya yang harus dibayarkan jika menjadi anggota.

\section{Saran}

FCTC sudah berlaku sejak tanggal 27 Februari 2005 hingga sekarang. Namun Indonesia belum meratifikasi FCTC tentunya dengan berbagai macam pertimbangan. Setelah melihat sejauh mana FCTC dapat memberikan perlindungan bagi kesehatan atas tembakau dan keefektifannya di dalam penerapan serta dampak yang besar bagi perekonomian nasional, maka penulis dalam hal ini menyarankan agar pemerintah tetap tidak meratifikasi FCTC yang lebih banyak memiliki dampak negatif daripada positif jika diratifikasi.

Penulis memberikan solusi agar pemerintah Indonesia tetap membuat suatu aturan tersendiri yang bersifat nasional untuk mengendalikan tembakau. Seperti halnya China dan Amerika Serikat yang membuat aturan sendiri mengenai pengendalian tembakau yang mana hal tersebut tidak merugikan perekonomian nasionalnya namun juga dapat mengendalikan tembakau secara efektif. Indonesia dalam hal pengendalian tembakau mengikuti Amerika Serikat yang mana tidak meratifkasi FCTC dan kemudian membuat aturan sendiri mengenai pengendalian tembakau serta tata niaganya. Indonesia dapat membuat langkah-langkah strategis seperti yang di lakukan oleh Amerika Serikat dengan membuat aturan yang khusus mengatur tentang industri tembakau dalam negeri yang tentunya menguntungkan industri dalam negeri. 


\section{Daftar Pustaka}

\section{A. Buku}

Adolf, Huala, 1997. Hukum Ekonomi Internasional Suatu Pengantar, Jakarta: PT,Raja Grafindo Persada.

Ardhiwisastra, Yudha Bhakti, 2003. Hukum Internasional; Bunga Rampai, Bandung: PT Alumni.

Kinasih, Herjuno Ndaru, et,al., 2012. Tembakau, Negara dan Keserakahan Modal Asing, Jakarta: Indonesia Berdikari.

Kurnia, Titon Slamet, 2007, Hak atas Derajat Kesehatan optimalsebagai HAM di Indonesia, Bandung: Penerbit Alumni.

Kusumaatmadja, Mochtar dan Agoes, Etty R., 2003. Pengantar Hukum Internasional, Jakarta: PT, Alumni.

Mauna, Boer, 2010. Hukum Internasional: Pengertian Peranan Dan Fungsi Dalam Era Dinamika Global, Edisi kedua, Bandung: PT, Alumni.

Parthiana, I Wayan, 2002. Hukum Perjanjian Internasional, Bagian Pertama, Bandung: Penerbit Mandar Maju.

Pinandjaya, Okta; S, Waskito Giri, 2012. Muslihat Kapitalis Global: Selingkuh Industri Farmasi dengan Perusahaan Rokok AS, Jakarta: Indonesia Berdikari.

\section{B. Internet}

http://www.who.int/fctc/cop/sessions/new_treaty/en/index.html

WHO Framework Convention on Tobacco Control, Fifth-Sixth World Health Assembly.

http://www.who.int, Report on Global Tobacco Epidemic. http://www.antaranews.com/berita/313477/jumlah-perokok-indonesiaterbanyak-ketiga-di-dunia

Theweek.com/article/index/219209/indonesias-smoking-babies-epidemic www.depke s.go.id/index.php/berita/press-release/2078-merokokmembahaya kan-kesehatan-dan-merugikan-perekono mianmasyarakat.html

M.kompasiana.com/post/bisnis/2011/06/01/paradoks-cukai-rokok-pemasokrp-627-triliun-apbn-2011/

http://www.who.int/fctc/signatories_parties/en/index. html 